\title{
PENGARUH ANGKA POISSON DAN MODULUS GESER TANAH TERHADAP AMPLITUDO DAN FREKUENSI PADA PEMODELAN FONDASI BLOK TIDAK TERTANAM UNTUK MESIN DIESEL
}

\author{
Nur Ikhsan \\ Mahasiswa Teknik Sipil Universitas Bangka Belitung \\ Email: nrikhsan96@gmail.com
}

\section{Ferra Fahriani}

Staf Pengajar Jurusan Teknik Sipil Universitas Bangka Belitung

Email: $\underline{\text { 2__ferra@yahoo.com }}$

\section{Yayuk Apriyanti}

Dosen Teknik Sipil Universitas Bangka Belitung

Email : yayukapriyanti26@gmail.com

\begin{abstract}
ABSTRAK
Pada fondasi mesin, pemilihan angka Poisson $(\mu)$ dan modulus geser tanah $(G)$ menjadi hal penting dalam perencanaannya karena merupakan parameter-parameter dinamis tanah yang sangat berpengaruh pada frekuensi alami dan amplitudo getaran yang dihasilkan. Penelitian dilakukan dengan memodelkan fondasi jenis blok tidak tertanam dan menggunakan mesin diesel. Pada analisis statis, dihitung daya dukung dan penurunan, sementara analisis dinamis memperhitungkan frekuensi alami dan amplitudo getaran yang terjadi pada getaran vertikal dan horizontal. Pada analisis statis diperoleh daya dukung dengan metode Terzaghi $=551,500 \mathrm{kN} / \mathrm{m}^{2}$ dan daya dukung ijin $=183,813 \mathrm{kN} / \mathrm{m}^{2}$, sedangkan penurunan yang terjadi $=25,480 \mathrm{~mm}$. Pengaruh pemilihan angka Poisson $(\mu)$ dan modulus geser tanah $(G)$ dilakukan dengan cara membuat 3 variasi nilai yang akan digunakan pada analisis dinamis. Variasi 1 dengan $\mu=0,1$ dan $G=204,5455 \mathrm{ton} / \mathrm{m}^{2}$, Variasi 2 dengan $\mu=0,2$ dan $G=281,250$ ton $/ m^{2}$ serta Variasi 3 dengan $\mu=0,3$ dan $G=$ $346,1538 \mathrm{ton} / \mathrm{m}^{2}$.Pemilihan angka poisson dan modulus geser tanah memberikan pengaruh terhadap frekuensi alami dan amplitudo getaran yang dihasilkan. Semakin tinggi nilai angka poisson dan modulus geser tanah, maka nilai frekuensi alami dan amplitudo yang dihasilkan juga akan semakin tinggi. Namun, pada getaran vertikal terjadi penurunan untuk nilai amplitudo.
\end{abstract}

Kata Kunci: fondasi, mesin, frekuensi alami, amplitudo, getaran

\section{PENDAHULUAN}

Fondasi mesin merupakan elemen struktur yang digunakan untuk meneruskan beban dari mesin di atas fondasi ke dalam tanah. Perencanaan fondasi mesin lebih kompleks daripada fondasi yang hanya menerima beban 
statis karena dalam perencanaanya fondasi harus mampu menahan beban statis dan beban dinamis. Kemampuan dalam menahan beban dinamis ditentukan berdasarkan nillai frekuensi alami dan amplitudo yang dihasilkan dalam sistem fondasi mesin. Pada fondasi mesin, pemilihan angka Poisson dan modulus geser tanah menjadi hal penting dalam perencanaannya karena merupakan parameter-parameter dinamis tanah yang sangat berpengaruh pada frekuensi alami dan amplitudo getaran yang dihasilkan. Pemilihan angka Poisson dan modulus geser secara empiris tanah saat ini dinilai kurang akurat dikarenakan nilai-nilai tersebut dalam kisaran yang belum pasti. Karena itu perlu dilakukan penelitian lebih lanjut terhadap parameter tersebut.

Penelitian ini bertujuan untuk mengetahui pengaruh pemilihan angka Poisson dan modulus geser tanah terhadap frekuensi alami amplitudo getaran yang dihasilkan pada pemodelan fondasi mesin blok tidak tertanam untuk mesin diesel

\section{LANDASAN TEORI}

\section{Parameter Dinamis Tanah}

Analisis permasalahan tanah yang menerima beban dinamis seperti stabilitas timbunan terhadap beban gempa, interaksi tanah dengan struktur pada saat gempa, dan respon dinamis dari fondasi mesin membutuhkan input parameter dinamis tanah.

\section{Angka Poisson}

Angka Poisson (Poisson's Ratio) \ adalah rasio atau perbadingan antara regangan transversal (tegak lurus) terhadap regangan longitudinal pada saat mengalami tegangan aksial, baik tarik maupun tekan, di dalam kondisi elastis.

Tabel 1. Perkiraan angka Poisson

\begin{tabular}{|l|c|}
\hline \multicolumn{1}{|c|}{ Jenis Tanah } & $\begin{array}{c}\text { Angka } \\
\text { Poisson }\end{array}$ \\
\hline Lempung Jenuh & $0,4-0,5$ \\
\hline Lempung Tak Jenuh & $0,1-0,3$ \\
\hline Lempung Berpasir & $0,2-0,3$ \\
\hline Lanau & $0,3-0,5$ \\
\hline Pasir Padat 0,2-0,4 & $0,2-0,4$ \\
\hline $\begin{array}{l}\text { Pasar Kasar }(\mathrm{e}=0,4- \\
0,7)\end{array}$ & 0,15 \\
\hline Pasir Halus (e =0,4 -0,7) & 0,25 \\
\hline Batu & $0,1-0,4$ \\
\hline Loess & $0,1-0,3$ \\
\hline
\end{tabular}

Sumber: Hardiyatmo, 2014

\section{Modulus Geser Tanah}

Modulus geser atau modulus kekakuan $\mathrm{G}$ menjelaskan kecenderungan sebuah objek untuk bergeser (deformasi bentuk pada volume konstan) ketika diberi kekuatan yang berlawanan;

Modulus geser tanah dapat ditentukan menggunakan nilai modulus elastisitas dan angka Poisson yang ditunjukkan dengan persamaan berikut:

$$
G=\frac{E_{g}}{2(1+\mu)}
$$


Tabel 2. Nilai Perkiraan Modulus

Elastisitas Tanah

\begin{tabular}{|l|c|}
\hline \multirow{2}{*}{ Jenis Tanah } & Modulus Elastisitas \\
\cline { 2 - 2 } Lempung & $(\mathrm{kg} / \mathrm{cm} 2)$ \\
Sangat Lunak & 42804 \\
Lunak & $20-40$ \\
Sedang & $45-90$ \\
Keras & $70-200$ \\
Berpasir & $300-425$ \\
\hline Pasir dan Krikil & \\
Padat & $800-2000$ \\
Tidak Padat & $500-1400$ \\
\hline Loess & $150-600$ \\
Serpih & $1400-14000$ \\
Kayu & $80.000-100.000$ \\
Beton & $200.000-300.000$ \\
Baja & 2.150 .000 \\
\hline
\end{tabular}

Sumber: Bowles, 1997

Fondasi Mesin

Fondasi mesin merupakan elemen struktur yang digunakan untuk meneruskan beban dari mesin di atas fondasi ke dalam tanah. Perencanaan fondasi mesin, umumnya lebih kompleks daripada fondasi yang hanya menerima beban statis. Selain perlu memperhitungkan gaya statis yang berasal dari berat mesin dan berat fondasi, perencanaan fondasi mesin juga harus memperhitungkan gaya dinams yang dihasilkan oleh mesin.

Praksash (1981) dalam Irsyam (2008) juga menyatakan bahwa fondasi mesin harus memenuhi kriteria desain berdasarkan beban statis maupun beban dinamis. Kriteria desan fondasi mesin berdasaran beban statis sebagai berikut :
1. Fondasi harus aman terhadap keruntuhan geser.

2. Fondasi tidak boleh mengalami penurunan tanah yang berlebihan.

Adapun kriteria desain fondasi mesin berdasarkan beban dinamis sebagai berikut :

1. Fondasi tidak boleh mengalami resonansi.

2. Amplitudo getaran yang terjadi tidak boleh melebihi nilai yang diizinkan.

3. Frekuensi alami dari sistem fondasi-mesin-tanah tidak boleh merupakan kelipatan bulat dari frekuensi operasi mesin.

4. Getaran yang diakibatkan oleh mesin tidak boleh menggangu ataupun memberikan efek buruk terhadap orang dan peralatan disekitarnya

Berikut tabel yang menunjukkan nilai amplitudo izin getaran.

Tabel 3. Nilai amplitudo izin untuk beberapa jenis mesin

\begin{tabular}{|c|l|}
\hline \multicolumn{1}{|c|}{ Jenis } & Amplitudo izin \\
\hline $\begin{array}{c}\text { Mesin berfrekuensi rendah } \\
\text { Mesin berfrekuensi tinggi }\end{array}$ & $0,02-0,025$ \\
3000 rpm & $0,1-0,12$ \\
Getaran vertikal & $0,002-0,003$ \\
Getaran horisontal & $0,004-0,005$ \\
1500 rpm & $0,004-0,006$ \\
Getaran vertikal & $0,007-0,009$ \\
Getaran horisontal &
\end{tabular}

Sumber: Irsyam, 2008

\section{Analisis Statis}

Pada analisis statis menghitung daya dukung dan penurunan yang terjadi 


\section{Daya Dukung}

Persamaan umum kapasitas dukung menggunakan Metode Terzaghi (1943) yang bersumber dari Hardiyatmo,2014 dapat dituliskan sebagai berikut:

$$
q_{u}=c_{2} N_{c}+D_{f} \gamma_{1} N_{q}+0,5 \gamma_{2} N_{\gamma} .
$$

\section{Penurunan}

Bila suatu lapisan tanah megalami pembebanan akibat beban di atasnya, maka tanah dibawah beban yang bekerja tersebut akan mengalai kenaikan tegangan, ekses dari kenaikan tegangan ini adalah terjadinya penurunan eleveasi tanah dasar (settlement).

\section{Penurunan Seketika}

$S_{i}=p_{o} \cdot B \cdot I_{p} \frac{(1-\mu)^{2}}{E_{s}}$

\section{Penurunan Konsolidasi Primer}

$S_{c}=\frac{C_{c} H_{c}}{1+e_{o}} \log \frac{p_{o}+\Delta p_{a v}}{p_{o}}$

$\Delta p_{a v}=\frac{1}{6}(\Delta p t+4 \Delta p m$

$\Delta p b \Delta p=\frac{q_{\circ} L B}{(B+Z)(L+Z) .}$

\section{Analisis Dinamis}

Perhitungan analisis dinamis meliputi dua arah getaran yakni vertical dan horizontal. Besarnya parameter dinamis menggunakan persamaan-persamaan berikut:

\section{a. Jari-jari ekivalen $r_{0 z}$,}

$r_{0 z}=\sqrt{\frac{A}{\pi}}$

\section{b.Rasio massa $B_{z}$,}

$B_{z}=\frac{1}{4}(1-\mu) m / \rho r_{0 z}^{3}$
c.Konstanta kekakuan $k_{z}$,

$k_{z}=\frac{4 G r_{0 z}}{1-\mu}$

d.Konstanta redaman $c_{z}$,

$c_{z}=\frac{3,4 r_{0 z}^{2} \sqrt{G \rho}}{1-\mu}$

e.Rasio redaman $D_{z}$,

$\left.D_{z}=\frac{0,425}{\sqrt{B_{z}}}\right)$

f.Frekuensi alami $f_{n}$,

$f_{n}=\frac{1}{2 \pi} \sqrt{k_{z} / m}$

g.Gaya dinamis $Q_{0}$,

$Q_{0}=$ Mmesin.e.f

h.Amplitudo getaran $A_{z}$,

$A_{z}=\frac{\left(Q_{0} / k_{z}\right)}{\sqrt{\left[1-\left(\omega^{2} / \omega_{n}^{2}\right)\right]^{2}+4 D_{z}^{2}\left(\omega^{2} / \omega_{n}^{2}\right)}}$

\section{METODE PENELITIAN}

Dalam penelitian ini dilakukan permodelan pondasi blok tidak tertanam untuk mesin diesel dengan memvariasikan nilai angka poison dalam modulus geser tanah . Langkah-langkan penelitian ini digamabarkan pada diagram alir pada gambar 1 


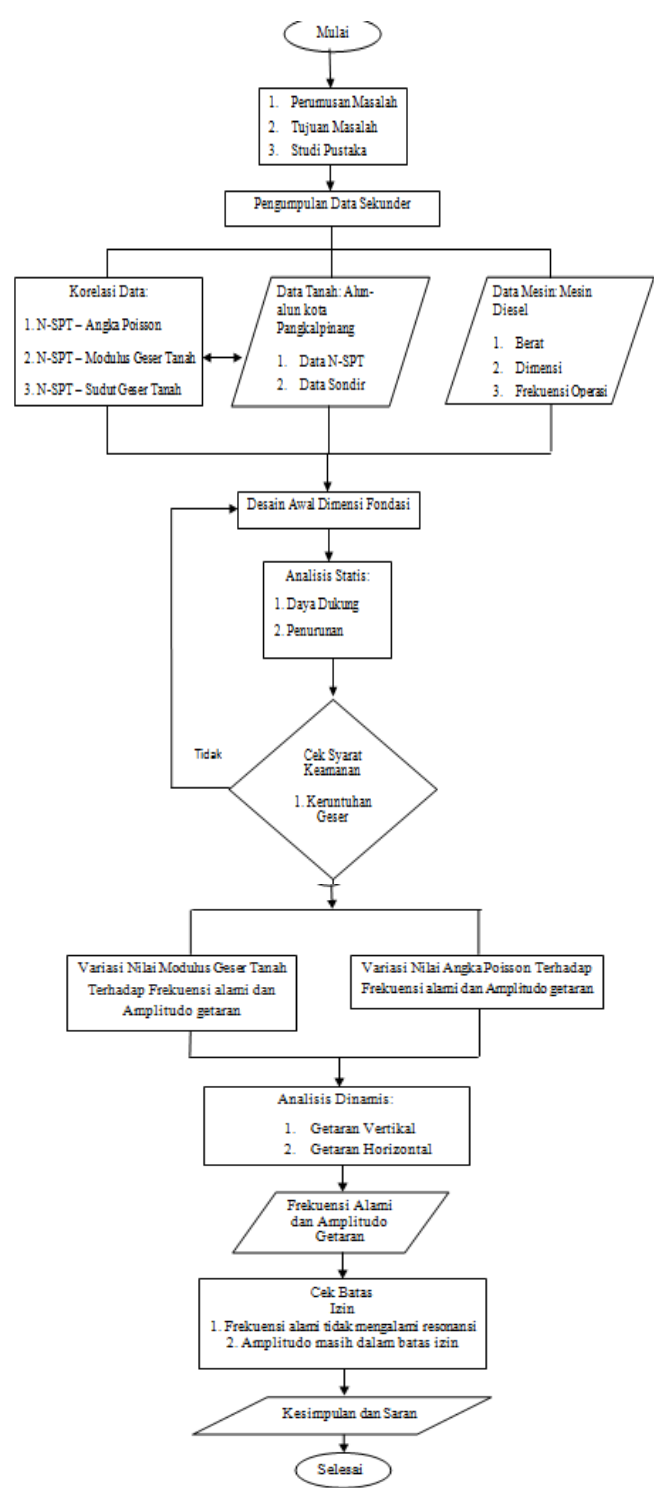

Gambar 1 Diagaram Alir Penelitian

Besarnya parameter-parameter yang digunakan dalam penelitian ini seperti yang diuraikan berikut

\section{Data Tanah}

Data tanah diperoleh dari Standard Penetration Test dan studi korelasi empirik

Tabel 4. Data Tanah

\begin{tabular}{|l|l|}
\hline Kedalaman & $0-2,2 \mathrm{~m}$ \\
\hline Jenis Tanah & Lempung Kelanauan \\
\hline N SPT & 8 \\
\hline Angka Pori (e) & 0.9 \\
\hline
\end{tabular}

\begin{tabular}{|c|c|}
\hline Kadar Air (w) & $30 \%$ \\
\hline Berat Jenis (Gs) & 2.715 \\
\hline Berat Volume (Y) & $1.858 \mathrm{t} / \mathrm{m} 3$ \\
\hline Sudut Geser $(\varphi)$ & $28^{\circ}$ \\
\hline Indeks Kompresitas(cc) & 0.189 \\
\hline Kohesi (cu) & $10 \mathrm{kN} / \mathrm{m3}$ \\
\hline
\end{tabular}

\section{Data Mesin}

Data mesin yang digunaka adalah sebagai berikut :

Tabel 5. Data Mesin

\begin{tabular}{|l|l|}
\hline \multicolumn{2}{|l|}{ Hyundai 14kVA Diesel Generator Single } \\
\hline Frekuensi (Hz) & 50 \\
\hline Kecepatan Operasi (Rpm) & 1500 \\
\hline Berat (ton) & $\mathbf{0 , 7 1}$ \\
\hline Dimensi LxWxH (m) & $1,5 \times 0,76 \times 1,070$ \\
\hline
\end{tabular}

\section{Pemodelan Pondasi}

Pondasi dimodelkan dengan memodelkan pondasi sebagai pondasi blok tidak tertanam yang berada pada tanah homogen dengan parametrer tanah seperti pada tabel 4. Pondasi direncanakan menahan beban mesin pada getran verikal dan horizontal dengan spesifikasi mesin seperti pada tabel 5

Pada pemodelan ini dilakuakan 3 variasi pemodelan dengan mevariasikan nilai angka poison dalam modulus geser tanah, seperti pada tabel 6. Penentuan nilai angka poisson dan modulus geser tanah berdasarkan tabel 1 dan tabel 2 
Tabel 6.Nilai Angka Poisson Dan

Modulus Geser Tanah

\begin{tabular}{|l|l|l|l|}
\hline & $\begin{array}{l}\text { Jenis } \\
\text { Tanah }\end{array}$ & $\begin{array}{l}\text { Angka } \\
\text { Poisson }\end{array}$ & $\begin{array}{l}\text { Modulus } \\
\text { Geser Tanah } \\
(\mathrm{kg} / \mathrm{cm} 2)\end{array}$ \\
\hline Variasi 1 & $\begin{array}{l}\text { Lempung } \\
\text { Kelanauan }\end{array}$ & $\mathbf{0 . 1}$ & $\mathbf{2 0 4 , 5 4 5 5}$ \\
\hline Variasi 2 & $\begin{array}{l}\text { Lempung } \\
\text { Kelanauan }\end{array}$ & $\mathbf{0 . 2}$ & $\mathbf{2 8 1 , 2 5 0}$ \\
\hline Variasi 3 & $\begin{array}{l}\text { Lempung } \\
\text { Kelanauan }\end{array}$ & 0.3 & 346,1538 \\
\hline
\end{tabular}

\section{HASIL DAN PEMBAHASAN}

Hasil perancanaan dimensi pondasi sebagai berikut

Tabel 7. Dimensi Fondasi

\begin{tabular}{|l|l|}
\hline \multicolumn{2}{|l|}{ Dimensi Fondasi (m) } \\
\hline Panjang & 1.9 \\
\hline Lebar & 1.16 \\
\hline Ketebalan & 0.268 \\
\hline
\end{tabular}

\section{Analisis Statis}

Berdasarkan Metode Terzaghi (1943) didapatkan daya dukung izin pondasi sebesar $q_{\alpha}=183,813 \mathrm{kN} / \mathrm{m}^{2} \quad$ dengan penurunan total sebesar $25,48 \mathrm{~mm}$

\section{Analisis Dinamis}

Hasil analisis dinamis, pada 3 variasi pemodelan pondasi menghasilkan nilai parameter dinamis yang berbeda seperti ditunjukkan pada tabel 8, tabel 9, dan tabel 10

Tabel 8.Hasil Analisi Dinamis Variasi 1

\begin{tabular}{|l|l|l|}
\hline Parameter & $\begin{array}{l}\text { Getaran } \\
\text { Vertikal }\end{array}$ & $\begin{array}{l}\text { Getaran } \\
\text { Horizontal }\end{array}$ \\
\hline Jari-jari ekivalen (r) & $\mathbf{0 . 8 3 7 8 ~} \mathbf{m}$ & $\mathbf{0 . 8 3 7 8 ~} \mathbf{~}$ \\
\hline
\end{tabular}

\begin{tabular}{|c|c|c|}
\hline Parameter & $\begin{array}{l}\text { Getaran } \\
\text { Vertikal }\end{array}$ & $\begin{array}{l}\text { Getaran } \\
\text { Horizontal }\end{array}$ \\
\hline Rasio Massa (B) & 0.4387 & 0.4198 \\
\hline $\begin{array}{l}\text { Konstanta } \\
\text { Kekakuan (K) }\end{array}$ & $\begin{array}{l}761.6374 \\
\text { ton/m }\end{array}$ & $\begin{array}{l}796.0340 \\
\text { ton } / \mathrm{m}\end{array}$ \\
\hline $\begin{array}{l}\text { Konstanta Redaman } \\
\text { (C) }\end{array}$ & $\begin{array}{l}16.5028 \text { ton- } \\
\text { detik/m }\end{array}$ & $\begin{array}{l}\text { 11.6678 ton- } \\
\text { detik/m }\end{array}$ \\
\hline Rasio Redaman (D) & 0.6417 & 0.4445 \\
\hline $\begin{array}{l}\text { Frekuensi Alami } \\
\text { (fn) }\end{array}$ & $92.9862 \mathrm{~Hz}$ & $95.0627 \mathrm{~Hz}$ \\
\hline Gaya Dinamis (Qo) & 18.9925 & 18.9925 \\
\hline $\begin{array}{l}\text { Amplitudo Getaran } \\
\text { (A) }\end{array}$ & $0.0036 \mathrm{~mm}$ & $0.0039 \mathrm{~mm}$ \\
\hline
\end{tabular}

Tabel 9. Hasil Analisi Dinamis Variasi 2

\begin{tabular}{|l|l|l|}
\hline Parameter & $\begin{array}{l}\text { Getaran } \\
\text { Vertikal }\end{array}$ & $\begin{array}{l}\text { Getaran } \\
\text { Horizontal }\end{array}$ \\
\hline $\begin{array}{l}\text { Jari-jari ekivalen } \\
\text { (r) }\end{array}$ & $\mathbf{0 , 8 3 7 8 ~} \mathrm{m}$ & $\mathbf{0 , 8 3 7 8 m}$ \\
\hline Rasio Massa (B) & $\mathbf{0 , 3 9 0 0}$ & $\mathbf{0 , 4 1 1 3}$ \\
\hline $\begin{array}{l}\text { Konstanta } \\
\text { Kekakuan (K) }\end{array}$ & $\begin{array}{l}1178,1579 \\
\text { ton/m }\end{array}$ & $\begin{array}{l}1117,0682 \\
\text { ton/m }\end{array}$ \\
\hline $\begin{array}{l}\text { Konstanta } \\
\text { Redaman (C) }\end{array}$ & $\begin{array}{l}\mathbf{2 1 . 7 7 0 2} \text { ton- } \\
\text { detik/m }\end{array}$ & $\begin{array}{l}13,9633 \text { ton- } \\
\text { detik/m }\end{array}$ \\
\hline $\begin{array}{l}\text { Rasio Redaman } \\
\text { (D) }\end{array}$ & $\mathbf{0 , 6 8 0 6}$ & $\mathbf{0 . 4 4 9 1}$ \\
\hline $\begin{array}{l}\text { Frekuensi Alami } \\
\text { (fn) }\end{array}$ & $115,6501 \mathrm{~Hz}$ & $112,6119 \mathrm{~Hz}$ \\
\hline $\begin{array}{l}\text { Gaya Dinamis } \\
\text { (Qo) }\end{array}$ & $\mathbf{1 8 , 9 9 2 5}$ & 18,9925 \\
\hline $\begin{array}{l}\text { Amplitudo } \\
\text { Getaran (A) }\end{array}$ & $\mathbf{0 , 0 0 3 5} \mathrm{mm}$ & $\mathbf{0 , 0 0 4 0 ~} \mathrm{mm}$ \\
\hline
\end{tabular}

Tabel 10. Hasil Analisi Dinamis Variasi 3

\begin{tabular}{|l|l|l|}
\hline Parameter & $\begin{array}{l}\text { Getaran } \\
\text { Vertikal }\end{array}$ & $\begin{array}{l}\text { Getaran } \\
\text { Horizontal }\end{array}$ \\
\hline Jari-jari ekivalen (r) & $\mathbf{0 , 8 3 7 8 ~} \mathbf{m}$ & $\mathbf{0 , 8 3 7 8 m}$ \\
\hline Rasio Massa (B) & $\mathbf{0 , 3 9 0 0}$ & $\mathbf{0 , 4 1 1 3}$ \\
\hline $\begin{array}{l}\text { Konstanta } \\
\text { Kekakuan (K) }\end{array}$ & $\begin{array}{l}\mathbf{1 1 7 8 , 1 5 7 9} \\
\text { ton/m }\end{array}$ & $\begin{array}{l}\mathbf{1 1 1 7 , 0 6 8 2} \\
\text { ton/m }\end{array}$ \\
\hline $\begin{array}{l}\text { Konstanta } \\
\text { Redaman }(\mathbf{C})\end{array}$ & $\begin{array}{l}\mathbf{2 1 . 7 7 0 2} \text { ton- } \\
\text { detik/m }\end{array}$ & $\begin{array}{l}\mathbf{1 3 , 9 6 3 3} \\
\text { ton-detik/m }\end{array}$ \\
\hline
\end{tabular}




\begin{tabular}{|l|l|l|}
\hline Parameter & $\begin{array}{l}\text { Getaran } \\
\text { Vertikal }\end{array}$ & $\begin{array}{l}\text { Getaran } \\
\text { Horizontal }\end{array}$ \\
\hline Rasio Redaman (D) & $\mathbf{0 , 6 8 0 6}$ & $\mathbf{0 . 4 4 9 1}$ \\
\hline $\begin{array}{l}\text { Frekuensi Alami } \\
\text { (fn) }\end{array}$ & $115,6501 \mathrm{~Hz}$ & $\begin{array}{l}\mathbf{H z} \\
\mathrm{Hz}\end{array}$ \\
\hline Gaya Dinamis (Qo) & $\mathbf{1 8 , 9 9 2 5}$ & $\mathbf{1 8 , 9 9 2 5}$ \\
\hline $\begin{array}{l}\text { Amplitudo Getaran } \\
\text { (A) }\end{array}$ & $\mathbf{0 , 0 0 3 5} \mathrm{mm}$ & $\mathbf{0 , 0 0 4 0 ~} \mathrm{mm}$ \\
\hline
\end{tabular}

Hasil perhitungan analisis dinamis disusun dalam bentuk grafik agar memudahkan untuk melihat hasil secara keseluruhan.

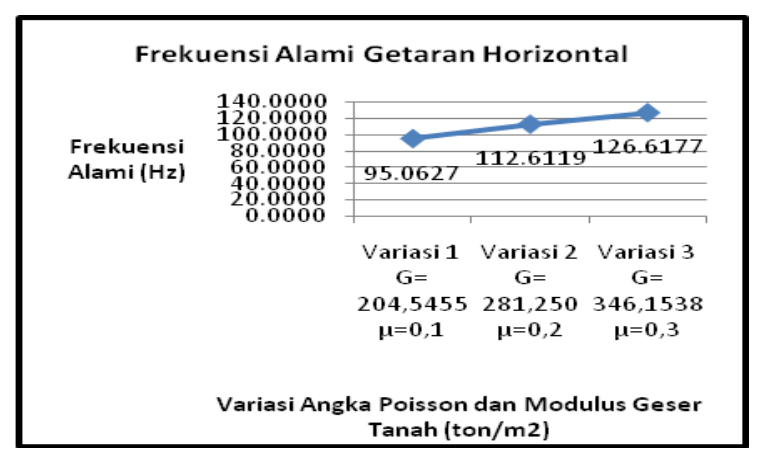

Gambar 2. Grafik Frekuensi Alami pada Getaran Horizontal

Berdasarkan hasil perhitungan persentase kenaikan dari variasi 1 ke variasi 2 frekuensi alami pada getaran horizontal sebesar $18,46 \%$, sedangkan kenaikan dari variasi $2 \mathrm{ke}$ variasi 3 sebesar $12,44 \%$.

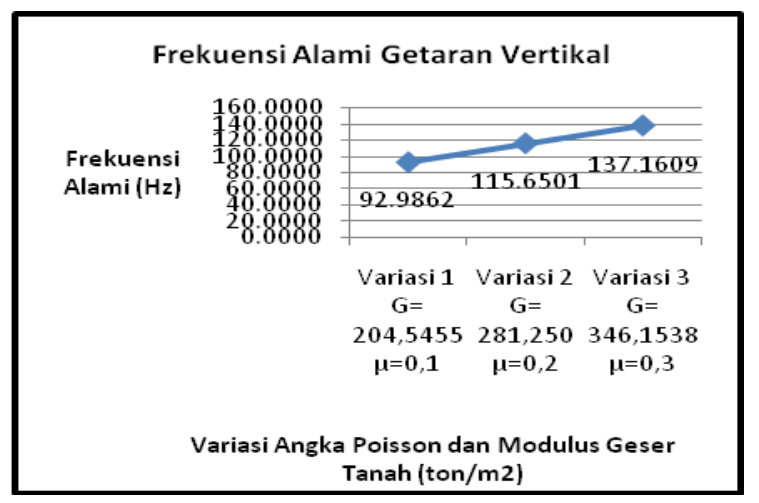

Gambar 3. Grafik Frekuensi Alami pada Getaran Vertikal
Berdasarkan hasil perhitungan persentase kenaikan dari variasi $1 \mathrm{ke}$ variasi 2 frekuensi alami sebesar 24,37\%, sedangkan kenaikan dari variasi 2 ke variasi 3 sebesar $18,60 \%$.

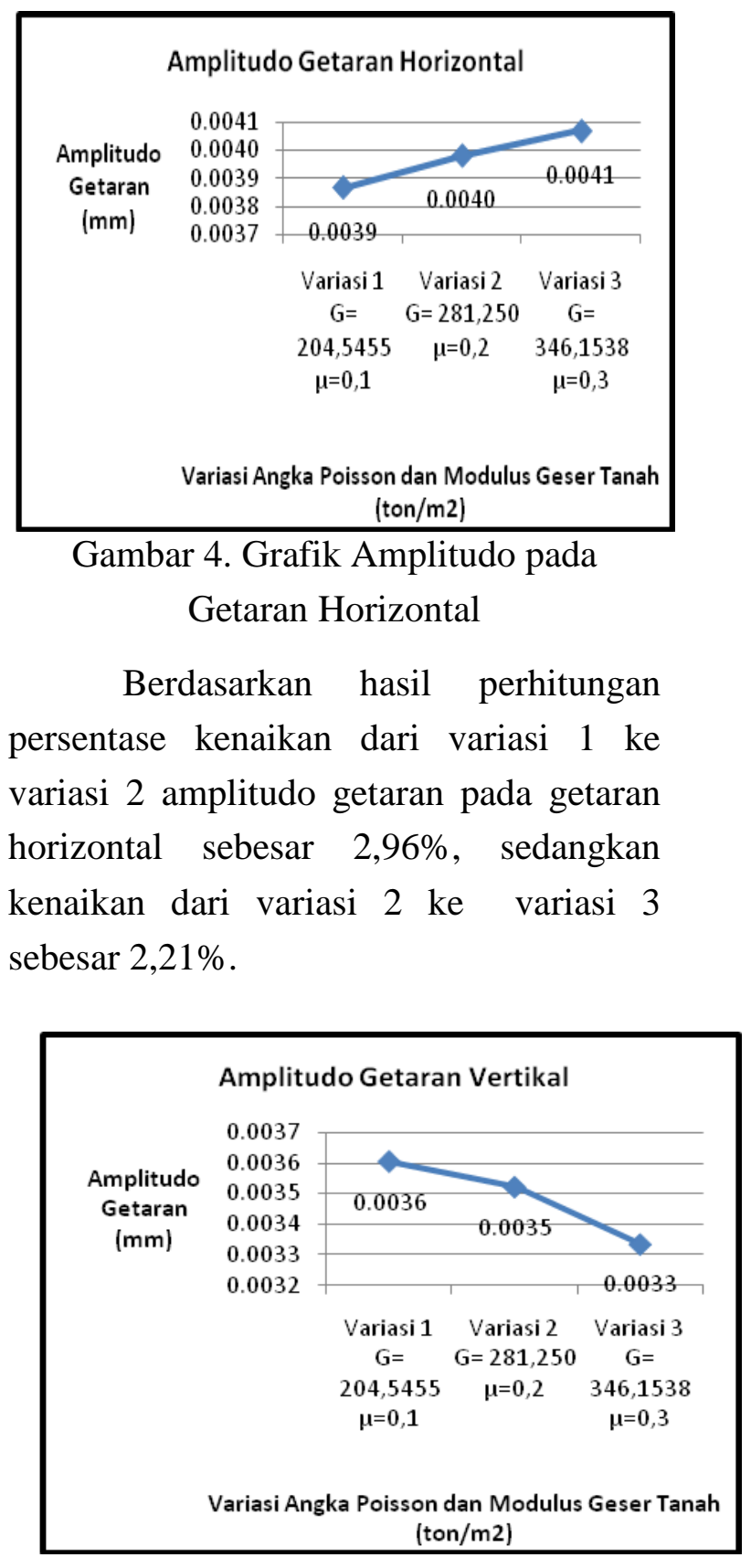

Gambar 5. Grafik Amplitudo pada

Getaran Vertikal

Berdasarkan hasil perhitungan terjadi penurunan dari variasi 1 ke variasi 2 amplitudo getaran menurun sebesar 
$2,29 \%$, sedangkan dari variasi 2 ke variasi 3 menurun sebesar 5,27\%.

Setelah diperoleh nilai frekuensi alami dan amplitudo getaran yang terjadi, diperiksa apakah memenuhi syarat atau tidak. Untuk persyaratan frekuensi alami Prakash, (1981) menyatakan bahwa frekuensi alami tidak boleh merupakan kelipatan bilangan bulat dari frekuensi mesin.

Tabel 11. Batas Ijin Frekuensi Getaran Horizontal

\begin{tabular}{|c|c|c|c|}
\hline Frekuensi Alami & $\begin{array}{c}\text { Horizon } \\
\text { tal }\end{array}$ & $\begin{array}{c}\text { Batas } \\
\text { Ijin }\end{array}$ & \\
\hline $\begin{array}{c}\text { Variasi } 1 \\
204,5455 \quad \mu=0,1\end{array}$ & 95.0627 & $\begin{array}{c}\neq 50 \\
\mathrm{~Hz} \\
\text { Bukan }\end{array}$ & $\begin{array}{l}\mathrm{O} \\
\mathrm{K}\end{array}$ \\
\hline $\begin{array}{c}\text { Variasi } 2 \\
281,250 \quad \mathrm{G}= \\
\mu=0,2\end{array}$ & $\begin{array}{c}112.611 \\
9\end{array}$ & $\begin{array}{c}\text { Kelipat } \\
\text { an } \\
\text { Bilang }\end{array}$ & $\begin{array}{l}\mathrm{O} \\
\mathrm{K}\end{array}$ \\
\hline $\begin{array}{c}\text { Variasi } 3 \\
346,1538 \quad \mu=0,3\end{array}$ & $\begin{array}{c}126.617 \\
7\end{array}$ & $\begin{array}{c}\text { an } \\
\text { Bulat }\end{array}$ & $\begin{array}{l}\mathrm{O} \\
\mathrm{K}\end{array}$ \\
\hline
\end{tabular}

Tabel 12. Batas Ijin Frekuensi Getaran

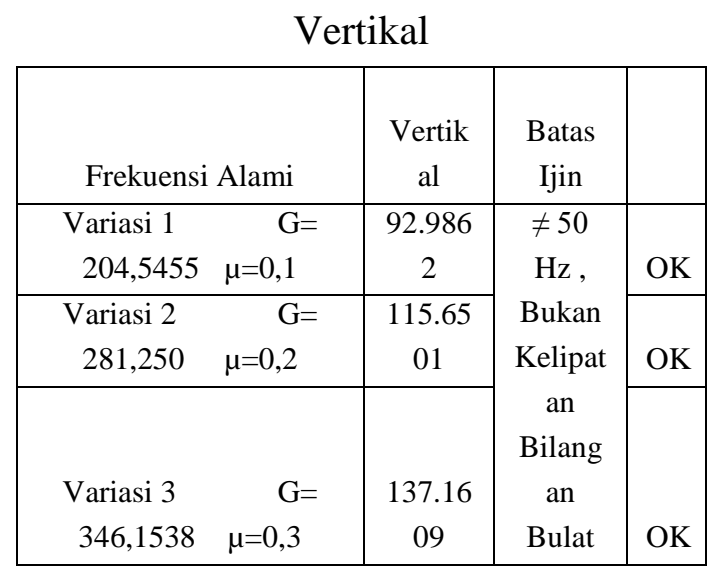

Tabel 13. Batas Ijin Amplitudo Getaran Horizontal

\begin{tabular}{|c|l|c|c|}
\hline Amplitudo & $\begin{array}{l}\text { Horizo } \\
\text { ntal }\end{array}$ & $\begin{array}{c}\text { Batas } \\
\text { Ijin }\end{array}$ & \\
\hline Variasi $1 \quad \mathrm{G}=$ & & $\leq 0,007$ & \\
$204,5455 \quad \mu=0,1$ & 0.0039 & $-0,009$ & OK \\
\hline
\end{tabular}

\begin{tabular}{|c|c|c|c|c|}
\hline Amplitudo & & $\begin{array}{l}\text { Horizo } \\
\text { ntal }\end{array}$ & $\begin{array}{c}\text { Batas } \\
\text { Ijin }\end{array}$ & \\
\hline $\begin{array}{c}\text { Variasi } 2 \\
281,250\end{array}$ & $\begin{array}{r}\mathrm{G}= \\
\mu=0,2\end{array}$ & 0.0040 & & OK \\
\hline $\begin{array}{l}\text { Variasi } 3 \\
346,1538\end{array}$ & $\begin{array}{r}\mathrm{G}= \\
\mu=0,3\end{array}$ & 0.0041 & & OK \\
\hline
\end{tabular}

Tabel 14. Batas Ijin Amplitudo Getaran Vertikal

\begin{tabular}{|c|c|c|c|}
\hline Amplitudo & Vertikal & Batas Ijin & \\
\hline Variasi 1 & & \multirow{6}{*}{$\begin{array}{c}\leq 0,004- \\
0,006\end{array}$} & \\
\hline $204,5455 \mu=0,1$ & 0.0036 & & $\mathrm{OK}$ \\
\hline Variasi 2 & & & \\
\hline $281,250 \quad \mu=0,2$ & 0.0035 & & $\mathrm{OK}$ \\
\hline Variasi 3 & & & \\
\hline $346,1538 \quad \mu=0,3$ & 0.0033 & & $\mathrm{OK}$ \\
\hline
\end{tabular}

Syarat amplitudo izin fondasi dinamis menurut Prakash (1981) yang bersumber dari Irsyam (2008) bahwa amplitudo yang terjadi tidak boleh melebih amplitudo izin.

\section{PENUTUP}

Berdasarkan hasil analisis dan pembahasan pengaruh angka poisson dan modulus geser tanah terhadap amplitudo dan frekuensi pada pemodelan fondasi blok tidak tertanam, diperoleh kesimpulan sebagai berikut:

1. Pemilihan angka poisson dan modulus geser tanah memberikan pengaruh terhadap frekuensi alami yang dihasilkan pada pemodelan fondasi mesin blok tidak tertanam untuk mesin diesel. Semakin tinggi nilai angka poisson dan modulus geser tanah, maka nilai frekuensi alami yang dihasilkan juga akan semakin tinggi.

2. Pemilihan angka poisson dan modulus geser tanah memberikan 
pengaruh terhadap amplitudo getaran yang dihasilkan pada pemodelan fondasi mesin blok tidak tertanam untuk mesin diesel. Semakin tinggi nilai angka poisson dan modulus geser tanah, maka nilai amplitudo yang dihasilkan pada akan meningkat. Namun, pada getaran vertical terjadi penurunan nilai amplitudo.

\section{SARAN}

Berdasarkan hasil analisis dan pembahasan, penulis ingin memberikan saran untuk penelitian selanjutnya sebagai berikut :

1. Penelitian selanjutnya diharapkan dapat langsung mengambil studi kasus untuk hasil yang lebih baik.

2. Kevalidan data, baik itu data tanah maupun data mesin sebaiknya diperhatikan lebih teliti.

3. Pada penelitian selanjutnya, analisis dinamis sebaiknya mencangkup empat arah getaran.

\section{DAFTAR PUSTAKA}

Briaud, J,-L, 2013. Geotehnical Engineering: Unsaturated and Saturated Soils.Wiley: United States

Das, Braja M, 1995. Mekanika Tanah (Prinsip-prinsip Rekayasa Geoteknik), Jilid 1. Erlangga: Jakarta.

Hardiyatmo, H.C. 2002. Mekanika Tanah I, Edisi Ketiga. Yogyakarta: Gadjah Mada University Press.

Hardiyatmo, H.C. 2014. Analisis dan Perancangan Fondasi I, Edisi Ketiga. Yogyakarta: Gadjah Mada University Press.

Irsyam, dkk. 2008. Dinamika Tanah dan Fondasi Mesin. Bandung: Penerbit ITB.

Prakash, Shamser. 2006. Foundation for Vibrating Machines. Journal of Structural Engineering: India 